\title{
Resolving Tensions among Creative Departments through Brand Identity Definition: The Case Study of Pininfarina
}

\author{
Gérald Mazzalovo \\ Correspondence: Gérald Mazzalovo, Brand specialist, Member of the Center for Engaged Management Research \\ (CEMR) at Paris-Dauphine University, France
}

\author{
Received: January 15, 2016 Accepted: February 1, 2016 Online Published: February 26, 2016 \\ doi:10.11114/bms.v2i1.1414 \\ URL: http://dx.doi.org/10.11114/bms.v2i1.1414
}

\begin{abstract}
In 2007, the famous Italian car design firm Pininfarina decided to develop its own mono-branded finished goods business. The jump from exclusively B2B activities to B2C was a major strategic move. The project initiated with the formalization of a possible brand identity as being the necessary preliminary exercise. Through the study of all the design activities over 80 years of history and following a semiotic approach, brand aesthetics and ethics invariants were identified.

Four different design teams were involved in the project and 5 main findings were identified in the course of the project:

Tensions exist among the various design teams because of the lack of coherence in design and each pretends to interpret the brand in a more consistent way

The creative teams feel the need for a well-defined and formalized brand identity, providing some missing common creative guidelines characterizing he brand

The design teams participated actively and enthusiastically to the process of brand identity definition

The President's positive attitude towards the project and his direct involvement have been essential in the project success

The tensions among the design teams have decreased by the brand identity definition process and results

The study had direct academic and operational implications:

It proved the validity of the semiotic approach to the formalization of brand identity

A diagnostic tool was created to measure the degree of consistency of any designed brand manifestation (car, advertising, architecture, car show installations...) with respect to the defined brand ethics and aesthetics.

Finally, Pininfarina presented a special concept car (Sintesi) at the Geneva car show in 2008 that integrated all the elements of the newly defined brand identity.
\end{abstract}

Keywords: designer, brand identity, semiotics, tensions reduction

\section{Introduction}

In December 2006, Andrea Pininfarina (AP), President and CEO of one of the oldest and worldwide leading Italian car design firm invited a few brand specialists to a meeting at the company's headquarters in Cambiano (a town in the Province of Turin in the Italian region) in order to explore the possibilities to develop the brand of Pininfarina. He started the meeting declaring: "I want to make money with my brand, just as Ferrari is doing with his." At that time, Pininfarina had never designed and sold mono-branded products under its own brand. This was the starting of a consultancy project, which started with the definition and formalization of the Pininfarina possible brand identity and concluded in 2008, with a detailed business plan to launch mono-branded products and services.

In this particular context of a project intended to develop "Business to Consumer" (B2C) activities for a product Designer exclusively servicing other brands, this paper shows how the definition of the brand identity helps to reduce

\footnotetext{
${ }^{1}$ In 2006, Ferrari was already invoicing more with derivative objects (Clothing, accessories, books, games, etc.) than with the approximately 6000 cars sold yearly.
} 
existing pressures among the creative, business and engineering sensibilities (Chiapello, 1998; Johansson \& Holm, 2006; Michlewski, 2008).

\subsection{A Brief History of Pininfarina ${ }^{2}$}

Battista "Pinin" Farina was born in Turin during 1893. He began to work at age 11, in his older brother's car body shop. He founded Carrozzeria Pinin Farina in 1930 in order to design, engineer and assemble cars. It is the beginning of a long story of car design and development for most of the famous car brands: Alfa Romeo, Ferrari, Fiat, Lancia, Maserati, Peugeot, Cadillac, GM, Bentley, Volvo, Mercedes, etc. and now the Chinese brands such as AviChina, Chery, Changfeng, Brilliance and JAC. The privileged relationship with Ferrari has marked both firms history. During the period of 1950s to 2014, all of the Ferrari cars (except one by Bertone) have been designed by Pininfarina. The current President is Paolo Pininfarina, grandson of the founder. In 2006 the company is experiencing a restructuration of its activities. A manufacturing site has been closed and the group is refocusing on "industrial design, sustainable mobility and extracting value from the brand". The company has evolved from a car body-maker ${ }^{3}$ to a company involved in design, engineering and niche manufacturing for third-party companies. It is a service company active into a B2B environment.

Adding a mono-branded business targeted to the consumer market to the traditional B2B activities is a case of business diversification (Stern \& Henderson, 2004) as well as brand extension (Monga \& John, 2010). This is indeed very similar to what Ferrari did, when it started developing its derivative business in the early period of 2000: New products for new consumers. Pininfarina can be categorized as a designer brand (C.M. Moore, J. Fernie \& $\underline{S}$ Burt, 2000), but not exactly in the sense used for the fashion designers as it is exclusively active in a context of B2B environment. However, it meets all the requirements of a brand as defined by Lendrevie, (2009): it has a name, characteristic signs (logo, calligraphy...) and it can trigger emotions and mental representations with its customers ${ }^{4}$. What makes this desired transformation particularly relevant to the brand specialists is the fact that so far, Pininfarina has designed models for other companies and therefore acted essentially as the interpreter of someone else identity.

\subsection{Organization of the Design Function in Pininfarina}

As most of the leading traditional Italian car body-makers (Bertone, Giugiaro...), Pininfarina offers a full range of services from conception, design, engineering and manufacturing of cars. Its manufacturing and engineering competencies directly contribute to its design capability which in any case remains the foundation of the company reputation. The five Directors report to the President: Design, Image and Communication, Corporate Finance, the Centre of Aerodynamic and Acoustic Research and the General Manager who has the responsibility for Production, Engineering, Human Resources and Commercial activities.

The three Chief Designers report to The Design Director. The distribution of specific projects to each team is based on the skills and history of each of them. The team specialized by clients (Ferrari, Lancia, Peugeot, and Chinese car companies), car typology (Concept car, convertible, sedan, trucks), or specific parts (interior or exterior), etc. The team is composed of 6 to 7 car designers led by a design team leader (See Figure 1).

\footnotetext{
${ }^{2}$ Source: www.pininfarina.com [accessed August $15^{\text {th }} 2014$ ]

3 "Carozziere" in Italian is also translated as Coachbuilder (source: Carrozzieri Italiani 2008, published by ANFIA. Associazione Nazionale Filiera Industria Automobilistica.)

${ }^{4}$ A good demonstration of the emotions that the cars designed by Pininfarina can generate may be found in the proliferation of the clubs of owners of the Peugeot 406 Coupe. Almost 110000 cars were sold from 1996 till 2004. They still generate enthusiasm with their owners (refer to the sites www.406coupeclub.org for UK, www.clubcoupe406.net for France and many Internet forums).
} 


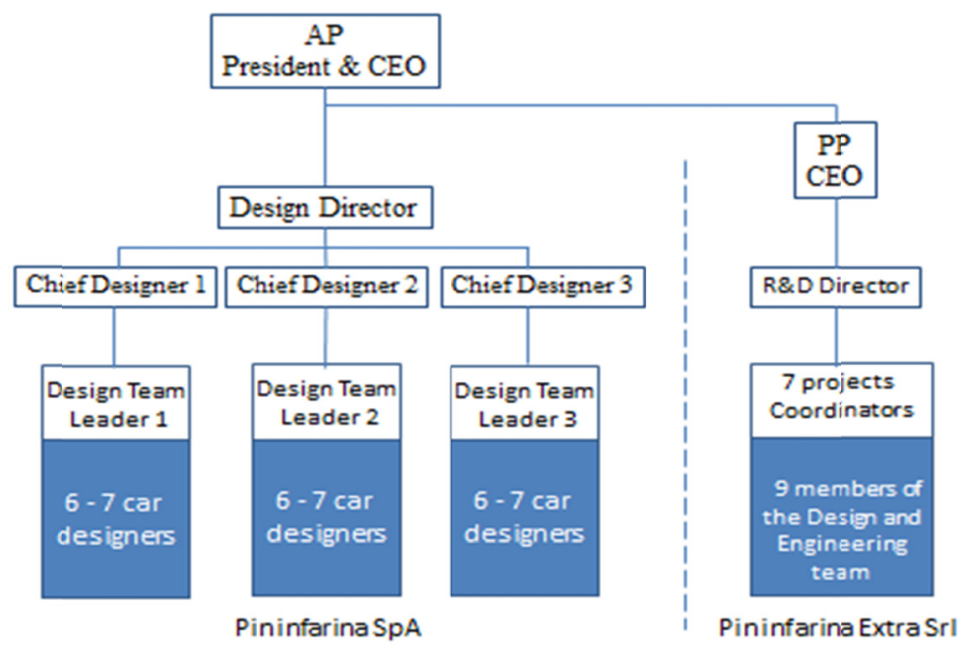

Figure 1. Pininfarina Schematic Design Organization (2007)

Pininfarina Extra $\mathrm{Srl}$ is a fully owned subsidiary created to develop design services for projects not related to the automotive industry (EXTRA: EXcept TRAnsport). Under the R\&D (Research and Development) Director there are 7 Project Coordinators and 9 members of the Design and Engineering team. He reports to the CEO (Paolo Pininfarina (PF), Andrea's brother).

We can therefore consider that we have 4 designing teams ( 3 automotive and 1 Extra) which work separately on specific projects. No specific training is planned for the newly hired designers. In the same way as the painting workshops of the renaissance painters were organized (Janson, 1995), the newly hired team learn by observing and participating in the projects, initially being involved in minor works and then progressively allowed into increasing amounts of creative participation through the recognition by his peers and team leaders of his capacities to contribute creatively and adequately to the projects.

\section{Methodology}

The study is based on a consultancy assignment resulting from a request from AP in 2007 to improve the financial results of the company through the conception, design and commercialization of Pininfarina mono-branded products. One of the paper's co-author led the consulting assignment. A process-focused qualitative case study design was selected (Eisenhardt, 1989; Langley, 2011) in order to concentrate on the change process which led to a reduction of the pressures, stress and tensions among the design departments. Koch (2014) quotes Dawson (2012) for a definition of process research as a "... real time study of changes as-it-happens over time defining the process research through the observed, documented and lived experiences of people as they seek to make sense and give sense individually and collectively to decision and non-decision making activities."

This was an ideal opportunity to apply the principles of process-focused qualitative research as through interviews of the main actors, their involvement in the definition and formalization of the Brand Identity and their consequential utilization of the results, we were able to observe and documents live experiences and changes of attitudes over time.

This article is also an example of Engaged Management Research design as supported by Van de Ven, (2007) who wrote that "Engaged scholarship is a participative form of research for obtaining the advice and perspectives of key stakeholders." In our case the stakeholders involved are some of the owners (AP and PP), the management, the designers and the researchers.

\subsection{Project Description}

The project team was composed of 3 consultants and the Communication and Image Director who functioned as the key interface for the internal project organization. PP served as Special Counsel to the team, in order to make sure that the point of view of the Extra team would be taken into account.

Regular reporting was made to AP during the 3 months of the first phase of the project.

The consultancy assignment required gaining the support of the several design teams. One way to ensure this support has been the inclusion in the project team, as one of the 3 consultants, of an external professional designer who through his intimate knowledge of the car design world, would contribute to gaining respect from the interlocutors and ensure the use of a proper tone and vocabulary in the interviews and questionnaires.

The corpus was made of pictures of cars and other objects designed since 1930, car shows stands designs, advertising 
campaigns, books [including the founder's biography, (1968)], architecture concepts of the headquarters and of the 3 assembly sites, specialized websites as well as financial reports, organograms, markets' data, customers, competition and design trends, press articles, etc.

Data were also gathered through 25 inside interviews (mainly of designers), guided by open questionnaires. We also performed some interviews outside the firm with Executives of Design institutions in Turin.

The project was structured into 2 main phases with the following objectives (See Figure 2):

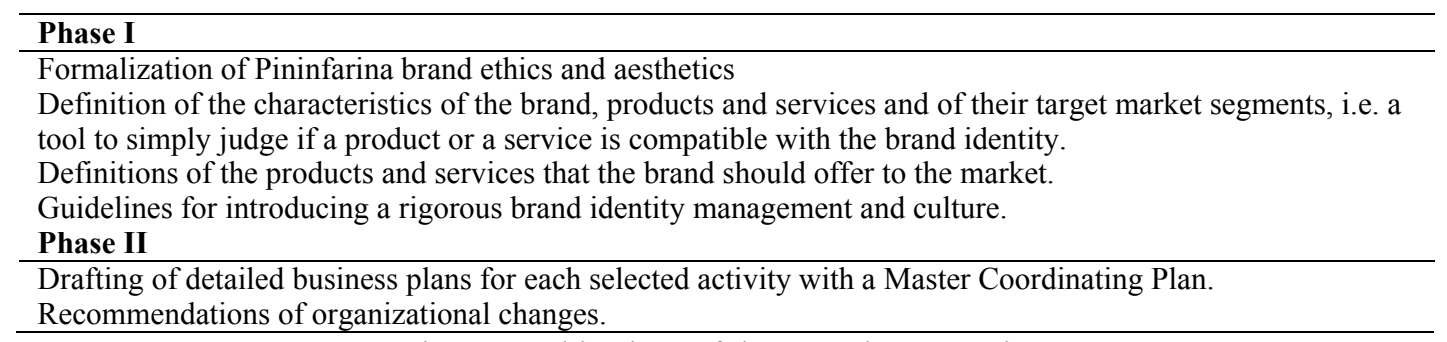

Figure 2. Objectives of the consultancy project

\subsection{Brand Identity}

The first objective of phase 1 was the formalization of the brand identity. We considered that at a time of developing mono-branded products, the formalization of Pininfarina brand identity was not only a significantly important reflexion process but also the first necessary methodological step. So far, the brand management logics were not really developed at Pininfarina; deciding to go after the B2C market with mono-branded products made the need for brand management unavoidable.

The identity-based brand management approach has developed strong support since early 1990's (Kapferer, 1992; Upshaw, 1995; Aaker, 1996; de Chernatony, 2006). According to Burmann and Al, (2009) consider the notion of brand identity as the theoretical basis of their brand equity model. As per the O'Shaughnessy, (1987) is quoted by Burmann and Al, (2009) as stating that: "Brand identity constitutes a necessary condition for maintaining buyer's trust, which in turn is the basis for long-term customer relationship and brand loyalty."

We also consider (Chevalier \& Mazzalovo, 2004 and 2012; Mazzalovo, 2012), as per the findings of these studies are going to confirm that a clearly formalized brand identity is a major federating tool for all the creative and communicating departments, ensuring a strong coherence in all of the brand manifestations.

The last reason which led us to choose to start the project by a brand identity definition is due to the fact that the identity issues are at the heart of the nature of the design activities. The designer needs to constantly resolve the dilemma existing between the brand own identity and his own "point of view". As he is supposed to interpret the clients brand identity without renouncing his own. Ferrari, like Peugeot, comes to Pininfarina for its specific way of designing cars, for its unique interpretation of their brand within the context of a particular project. Haute Couture and Ready-to-Wear, because many designers work both on a brand collection as well as on their own, offer various examples on how the identity dilemma is resolved. In general, Couturiers are either good interpreters of the brand they design for, or strong designer of their own brand. Karl Lagerfeld is a virtuoso interpreter of Chanel. The collection he markets under his own name has never known a great recognition. We could say the same for Galliano when he was designing Dior collections, whereas Narcisso Rodriguez has experienced better success with his own collections than for his work for Loewe in the late 1990's.

Theoretically, the formulation of Pininfarina own brand identity was developed using Floch's semiotic approach (1990 and 1995). Floch was a leading member of what has been called l'Ecole de Paris (Coquet, 1982), or the school of narrative semiotics (Groupe $\mu$, 1992) rooted in structuralist teachings of Greimas in the 1970's. Floch's brand identity scheme is based on Saussure's (1916) approach to sign (signifier and signified), then taken up by Hjelmslev, (1971). Floch's contribution is his focus on the invariant parts of the 2 levels of expression and content, in line also with Ricoeur's, (1990) notion of narrative identity. The scheme, later on called the brand identity hinge, has been taken up to illustrate specific brand issues by Heilbrunn, (2000); Semprini (1992 and 2005); Chevalier \& Mazzalovo, (2004 and 2012) and Mazzalovo \& Darpy, (2014) fundamental hypothesis of all the researchers who use the semiotic approach to brand identity is that brands need to produce meaning in order to be competitive.

\section{Findings}

Five key and interrelated findings were put as evidence:

1) Existence of Tensions Among the Design Teams 
There is a widespread feeling within the organization that the recent Pinifarina design projects may not have been as characteristic and homogeneously focused as before. Design team leader (3) declares: "In the past 15 years, our designs have been less coherent than before". The Deputy Communication Director is even more explicit: "In the past car body-makers used to have both the eye and the hand... I have sometimes the impression that we are left with the hand, how to recuperate the eye?"

This lack of coherence in design triggers tensions among the design teams. They respectively feel that they understand and interpret Pininfarina brand better, as expressed (very often with caution) in some interviews. Critics on design coherence focus primarily on the extra non-automotive design projects:

"Extra is designing beautiful objects... however not necessarily Pininfarina (Design Team Leader 3)

"There is a lot of heterogeneity in the non-automotive designs... It is pointless to try to systematically apply automotive lines and shapes to non-automotive products."

"I do not know them (Extra) well... we are very much apart." (Design Director)

"The Extra contract with Keating to design a hotel in California should have been managed more rigorously. The Ferrari red which has been used in the decoration is not a characteristic of Pininfarina."

"The small objects (Extra) are often over-designed."

"The design of the jet interior reflects ostentatious, old luxury, without soul."

"There is no common vision between Extra and the car design teams yet what is the difference between a car and a jet plane interior design?" (Deputy Communication Director).

"In their field (Extra), you can design without being a specialist and therefore perhaps being more innovative. However, beware of gratuitous design." (Chief Designer 3)

"The contracts of Extra with its clients do not include clauses related to Pininfarina image (e.g. Snaidero)." (Communication and Image Director).

"There is a gap between the worlds of Car Design and Extra."

"Extra has the tendency to transfer a specific car design language into other objects."(Director of a Turin Design School)

\section{These perceptions are also shared by some Extra's employees:}

"Certain objects have been overdesigned (divani Nieri) and certain projects insufficiently controlled (Keating hotel)." (Extra R\&D Director)

These tensions are often expressed as a lack of communication among the design teams:

"There is an iron curtain in between the design departments." (Extra Commercial Director)

"It is a pity we do not work more together" (Chief Designer)

These communication difficulties among creative departments are reinforced by the professional project secrecy that the nature of the design work imposes as the Director of Communication and Image recognizes it: "The culture of secret creates difficulties for the communication department." It naturally affects also the rapports among the various design teams.

The organizational tensions go beyond the realm of the design departments. A few comments relate to the rapports Design has with the Engineering department:

"We are not integrated enough with the engineering."

"Even engineers need to have that sensibility... They are not very creative." (Design Team Leader 3)

"Engineers are not creative enough" (Head Designer for special projects)

\section{2) The Creative Team Feel the Need For a Well-defined Brand Identity}

Creative teams do not show any type of reticence with respect to brand logics, especially when exposed to the semiotic vocabulary and notions related to brand identity. There was already a strong awareness of the lack of guidelines for the management of the Pininfarina brand, hence the call from the Designers for more stringent and formalized guidelines that they expect the brand identity would provide. Some of the comments were quite explicit in expressing the need for a formalized brand:

"We never had any brand management as such; we relied on the exceptional individuals of the family." (Special projects Director). 
"Today we do not have a branding culture."

"There are obvious organizational issues in managing the brand. Who is supposed to have the best sensitivity to Pininfarina image?" (Deputy Communication Director).

"We all believe in the strength and potential of the brand". (Design Team Leader 3)".

"We have lack a proper discourse on the brand... We need a strong and coherent brand".

"A formalized brand is necessary for the car design teams, but is even more important for the Extra team".

(Vice-Director Business Development for Style and Engineering).

\section{3) The Design Teams Actively Participate to the Process of the Brand Identity Definition}

All of the contributions of designers have been essential in the formalization of the brand identity. They took the opportunity of the project to express their own vision on the brand. Their inputs brought vital contributions not only to the aesthetic dimension as it was expected but also on the ethics invariants.

We have gathered some examples of their input which contributed to the final formalization of the brand identity as can be seen on Figure: 4 which show the synthetic results, positioned on a brand hinge according to Floch's scheme.

"Pininfarina creates the most beautifully proportioned cars."

"Pininfarina has a unique holistic approach."

"Balance, iconic simplicity, elegance, sporty nature" (Head Designer for Special Projects. Design team 2)

"reserved, subdued... Piemontese."

"air..., aerodynamism”.

"Never a casual (or gratuitous) design." (Design Team Leader 3)

"Excellence, a particular relationship with time, Italian, proposing a dream." (Vice-Director Business Development for Style and Engineering).

"Harmonious proportions; cleanliness of the shapes; timelessness."

"It is not cosmetic design"

"Make the object expressive" (Design Team Leader 2)

"We are a luxury brand". (Managing Director)

"Air flow on surface... interfaces with nature... fluency, tension, balance, dynamism, nature, freedom..."

"Technological innovation as an aesthetic opportunity"

"Volumes/proportions... nothing casual or gratuitous... It is the whole which makes sense, not the single factor... geometric consistency..."

"Not only a style, a philosophy."

"Pininfarina, as a mediator, resolves the dialectic between earth and air".

“The Florida II (Figure 3), Pinin's personal car, is the ultimate symbol of Pininfarina philosophy: elegance, innovation, simplicity, refinement and dynamism." (Presentation on 19.1.2007 in occasion of the Mitomacchina exhibition) 


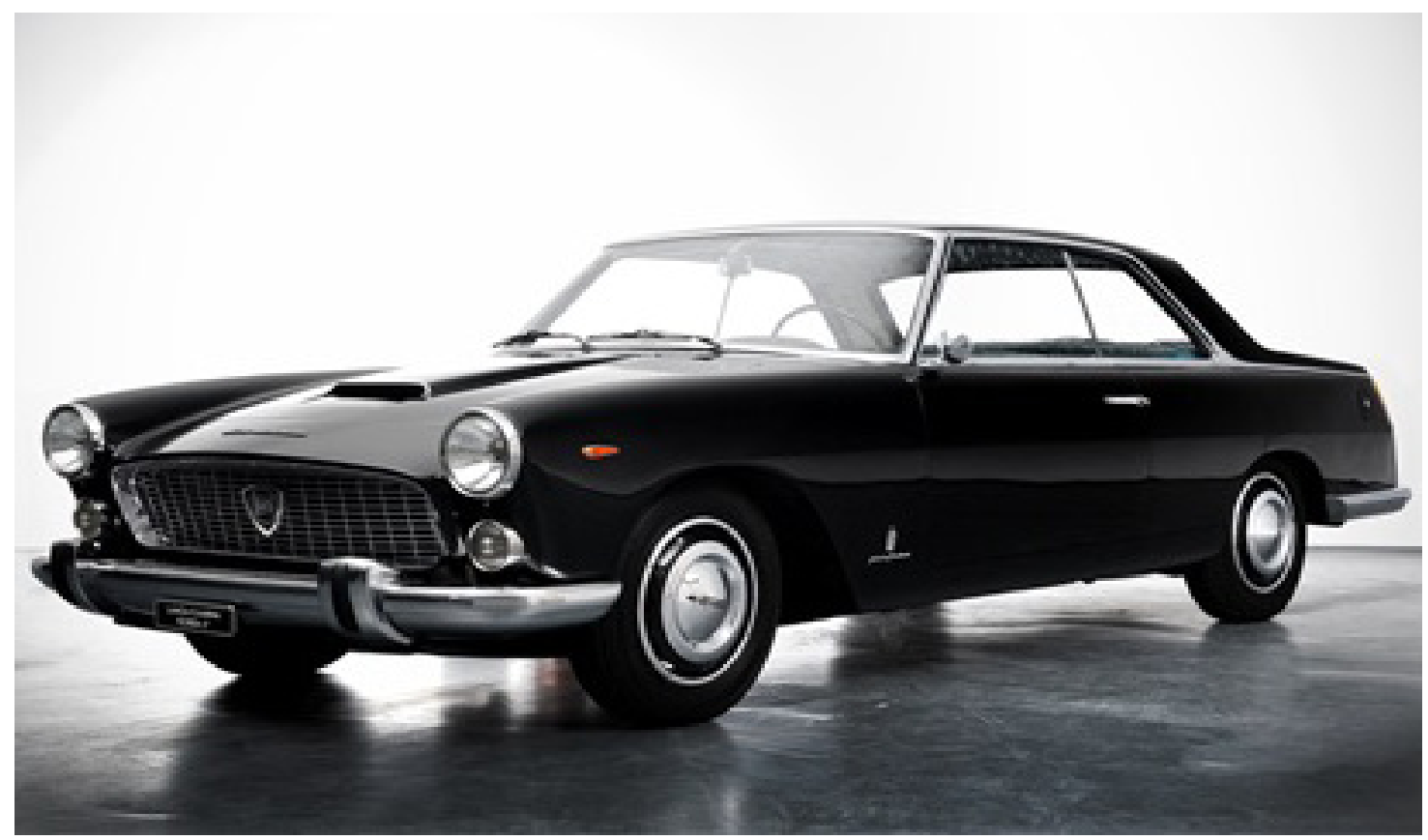

Figure 3. The Lancia Florida II Designed and Built by Pininfarina (1957)

"In this approach, we do not only create consistency in geometry but also in the character and the personality of the cars. And that what brings transparency and honesty in our approach, which keeps Pininfarina's cars current over time."

"Pininfarina's design is both simple and complex at the same time. The complexity is expressed in the volumes distribution, in the harmony of proportions, in the internal geometries of the shape... whereas the simplicity allows for an immediate communication of the car personality." (Design Director)

"Soft lines with tension, round shapes and corners, care in the treatment of surfaces, balance of volumes, innovative texture, dynamism that mean different front and rear view."

"Aerodynamics was and is in the heart of design through the generations"

"Elegance, essentiality, innovation." (PP)

"A perceived lightness" (AP)

"Dynamic, fluid, aerodynamics, lines of strong character, innovation, classicism, universal sporty, elegant, simple."

"Natural union of form and function."

"Always a serious intellectual project, never just aesthetic."

"Thinking forms according to social concern." (Chief Designer 1)

"Aesthetics that lasts; ethics of seriousness."

"We innovate, we find new aesthetic solutions."

"Smooth, classic and strong shapes the right curved surface ${ }^{5}$. the quality of the surface."

"Overcoming the constraints through aesthetics as a solution to technical and financial issues." (Chief Designer 3)

"Strong Piedmonteses culture... absence of a communication culture."

"A serious Piedmonteses engineer, great technical know-how; anti-fashion; very innovative, even if it may not seem to a non-specialist.” External observer (PR of Torino 2008. World design Capital).

"Un monstre sacré"

5 "Il bombato giusto" 
«Designers must be touched by nature genius.” External observer (Direttore dell'Istituto Europeo di Design) Torino

All of the staff interviewed insisted that their profession was the one of a car body-maker ${ }^{6}$, which is why we have included in the ethical invariants, the belief that Pininfarina is the ultimate car body-maker. From being a factual status, it becomes a value of the brand, a commitment applied to all creative and decision-making activities.

The comments and indications given by the interviewees were discussed in groups. The ultimate rationalization was prepared by the consulting team.

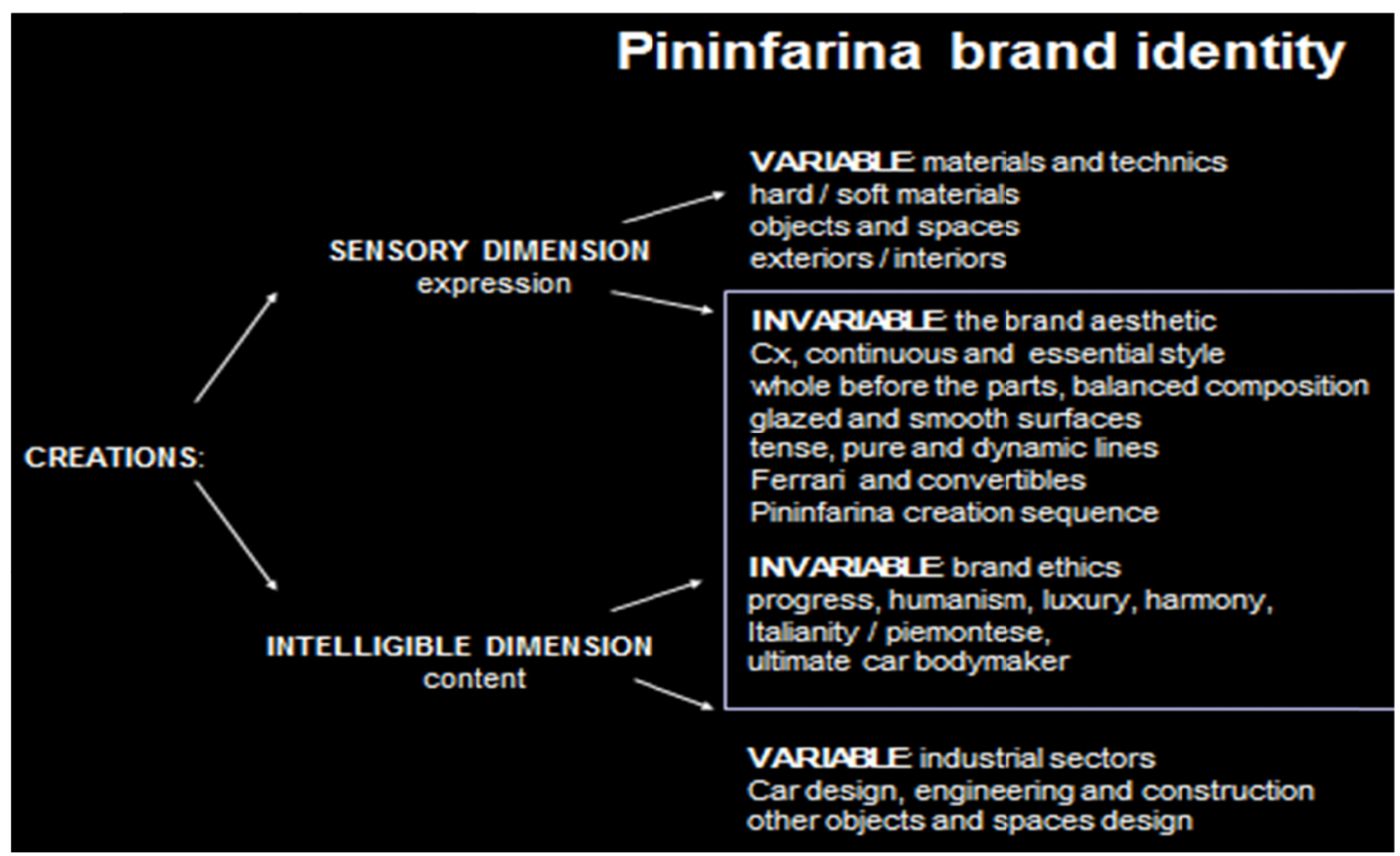

Figure 4. Pininfarina's Brand Identity Expressed According to Floch's Hinge

Another determining source of the brand identity has been the biography of Battista (Pinin) Farina, (1968). This document which had been somewhat forgotten if not never read by most of the designers, was welcomed as a fundamental basis for the brand aesthetics as it clearly characterized the founder's purpose. Battista declares:

"In my work in these times I thought about the line of the wind. Going in winter in the mountains I could see how the wind was shaping the snow at the edge of the road, sculpting either curved or sharp shapes... I wanted to copy those lines for my projects." (Page: 201).

"It was necessary to use new forms maybe copying from nature which is always modern and relevant; see the shapes of the birds, the beautiful profiles of certain fish, and also of certain fantastic insects." (Page: 55).

"I went often to the banks of the Po to observe the beautiful boats, their profile that never changes that I was seeing always as new in its slender simplicity." (Page: 33).

"I liked the cars with simple lines, sober, rather than with rich ornaments, artistic intentions." (Page: 23).

These statements allowed us to establish clearly what was to be called "The air connivance" (See Figure: 5) as the major organizing principles of the brand aesthetics which was subsequently used in the definition of the future mon-branded products and services.

Concluding on this third essential finding, we can also sustain that, beyond the obvious benefits of a strongly desired formalized Pininfarina brand identity that will be developed in the implication parts, the sheer participation of the design teams into the process of the brand identity definition has contributed greatly to the tension reduction among them. As it often happens, the process of participation of the protagonists acquires as much importance as the results themselves.

\footnotetext{
6 "Siamo carrozziere"
} 


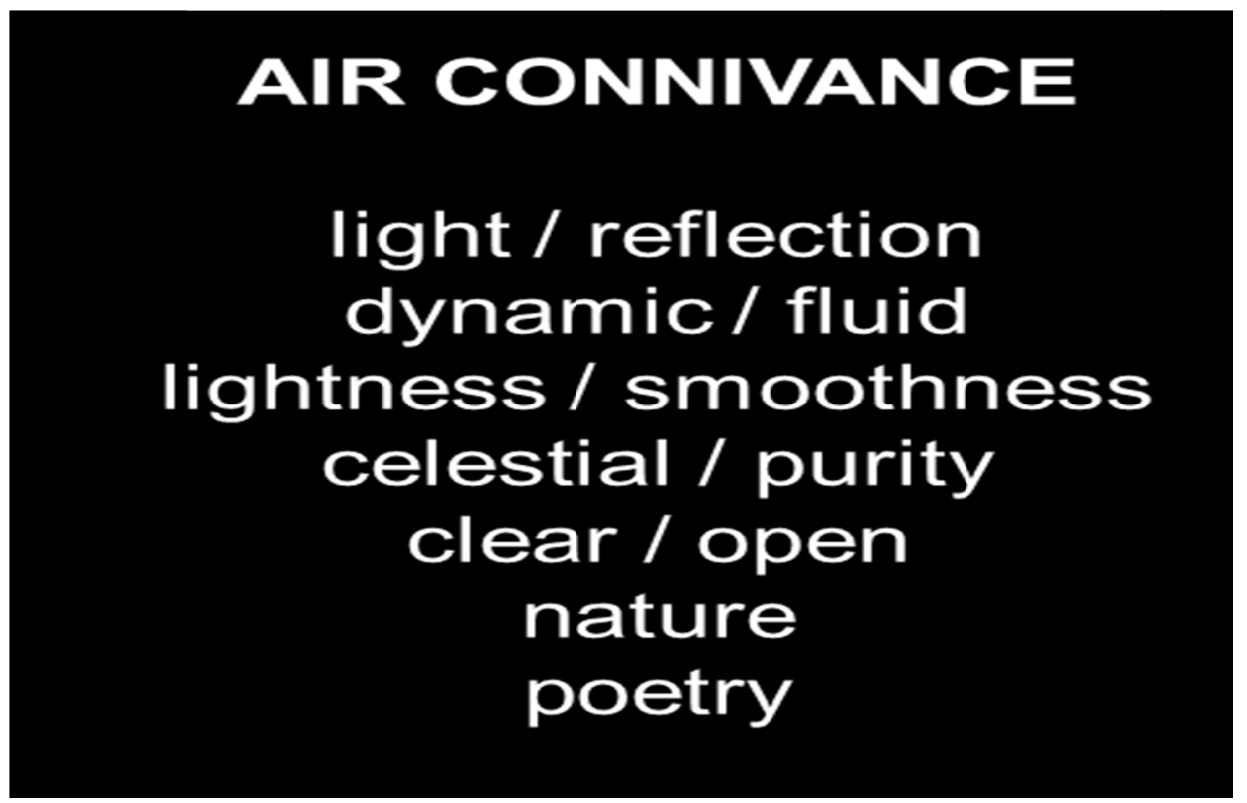

Figure 5. "Air Connivance" as the Organizing Principles of the Design of the Mono-branded Products

\section{4) The President's Attitude and Involvement has been Essential for the Success of Project}

By explaining the strategic importance of the project and showing his strong personal commitment, AP contributed to the Designers' motivation. The Pininfarina brand project was launched by AP in a formal meeting. In all occasions, he demonstrated how crucial the project was for the company's future. For instance, in a company monthly Design meeting, AP declared: "If we look at the 40 design projects we carried out in 2006, it appears clearly that we have to strive for a more integrated designs. Our own "writing" should be felt in all our creations. The brand definition project should not only help in developing our own mono-branded products but also give us clear guidelines in all our design works for other brands."

\section{5) Tensions Among the Design Teams are Resolved or at Least Reduced by the Brand Identity Definition} Process and Results

Strong evidence of tension reductions came in when we started using the results of the initial phase of the project. The Brand Identity definition was somewhat "institutionalized" after having been presented and accepted by the Board of Directors. Each Designer directly participated to the Brand Identity elaboration and could recognize his own contribution in the final version. The process gave a strong legitimacy to the results of the project and all participants felt committed to it.

The Brand Identity hinge was then developed into a diagnostic tool (the ESTET diagram, see Figures: 6 and 7) allowing for the measure of the degree of consistency of specific brand manifestations with the ethics and aesthetics invariants. It is a simple diagram made of two axes measuring the degree of consistency of a specific brand manifestation respectively with the aesthetic and ethic invariants. We organized several meetings with the design teams in order to make a judgement of coherence of the designs of past cars and objects with respect to the defined Brand Identity. All the Design teams agreed on the final results presented in Figures 6 and 7, demonstrating a capacity to work jointly and discuss rationally on aesthetics and ethics considerations on Pininfarina's designs. The process was applied also to the advertising, logos, etc. 


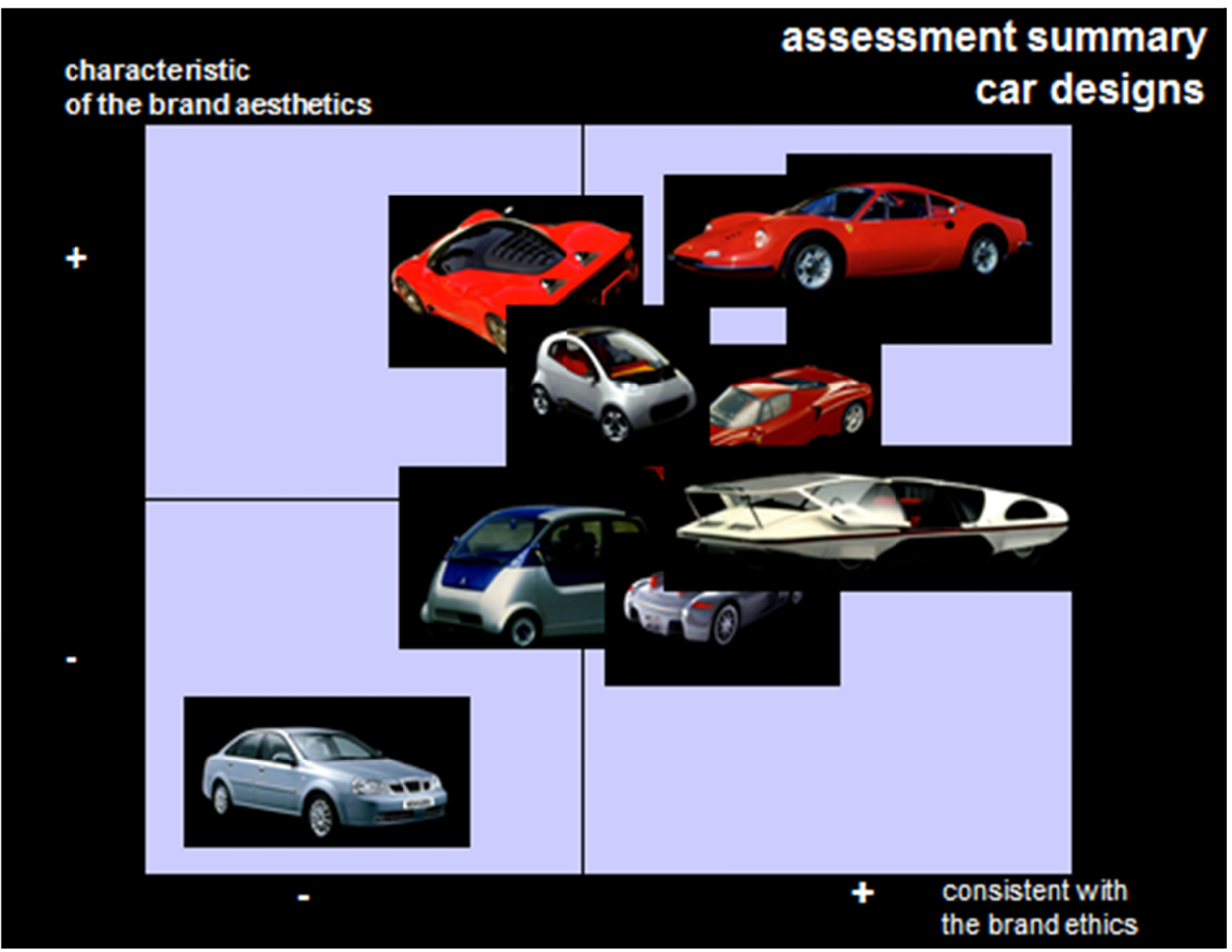

Figure 6. Evaluation of the Consistency of Various Historical Automotive Designs in Terms of Ethics and Aesthetics

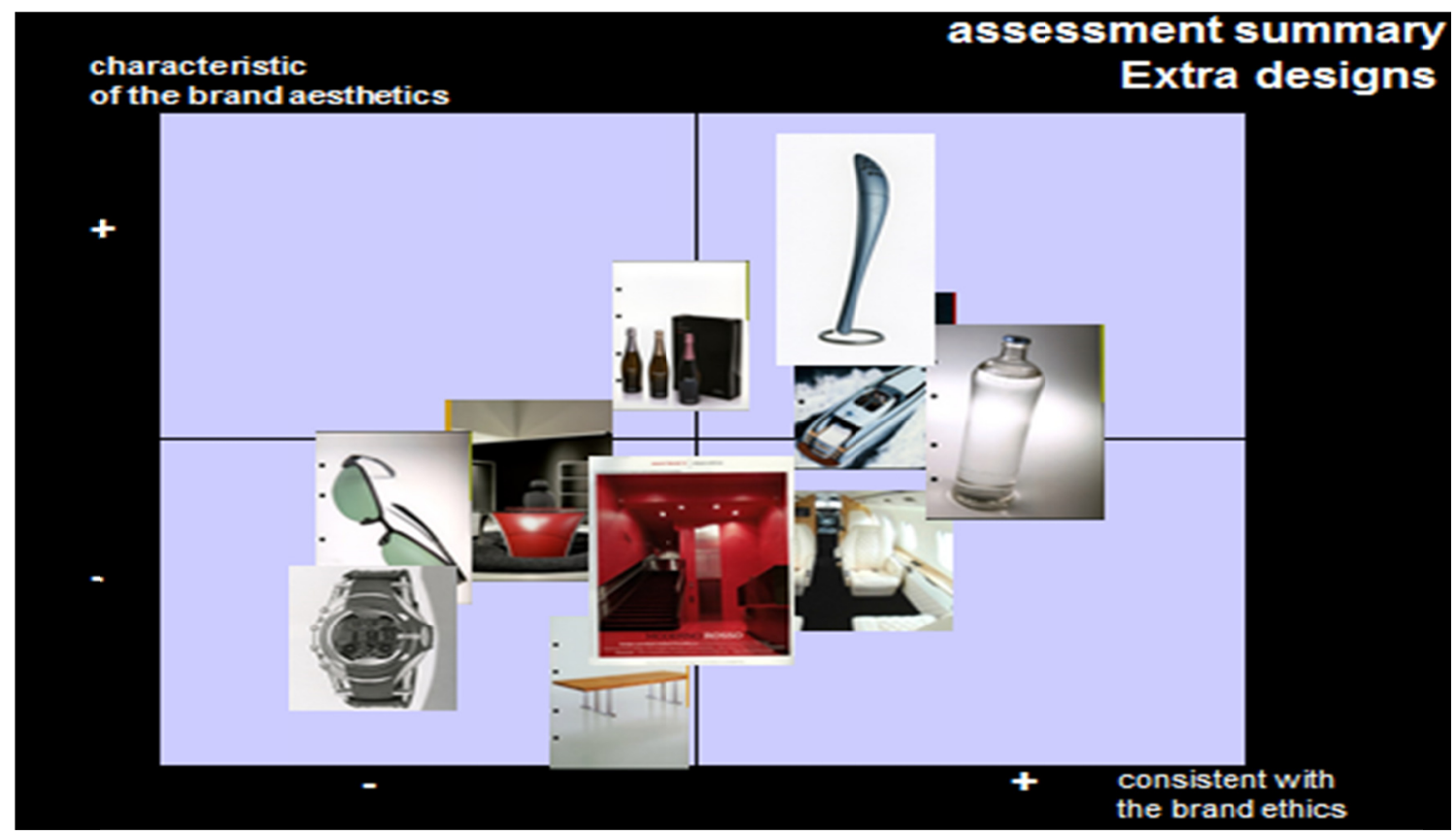

Figures 7. Evaluation of the Consistency of Various Historical Extra Objects Designs in Terms of Ethics and Aesthetics 3.1 Practical Implications

In addition to having demonstrated the usefulness of a clearly defined brand identity in appeased interrelationships among creative departments. The following tools and methodologies were developed:

A semiotic-based methodology to formalize a possible brand identity.

A diagnostic tool to measure the degree of coherence of any brand manifestation with respect to the ethic and aesthetic 
dimensions of a pursued brand identity (the EST-ET diagram).

\subsection{At Pininfarina's Level, There are Strategic and Operational Implications:}

The identity of the possible Pininfarina's brand has been defined in terms of ethics and aesthetics invariants.

The brand identity elements which came out of the formalization process have been integrated into the company communication and the creation of the concept car "Sintesi" (See Figure 8) and the electrical car (Bluecar) developed with the Bolloré Group's batteries. They serve as basic guidelines for all future projects.
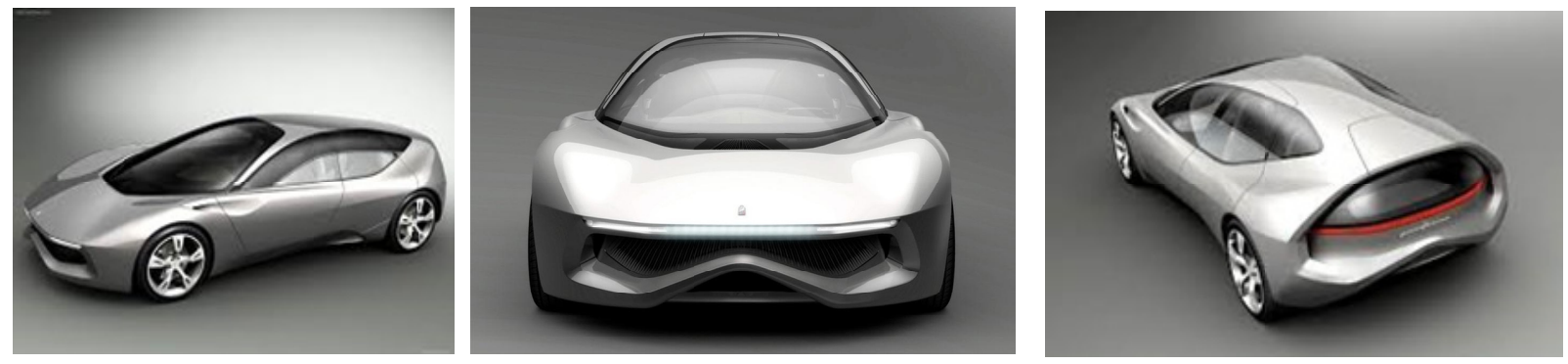

Figure 8. Pininfarina "Sintesi" Concept Car, (2008)

The Brand Identity study led to the development of a detailed possible brand universe which served as a basis to the strategic development plan of the new Pininfarina brand activities (product and service categories). See Figure 9.

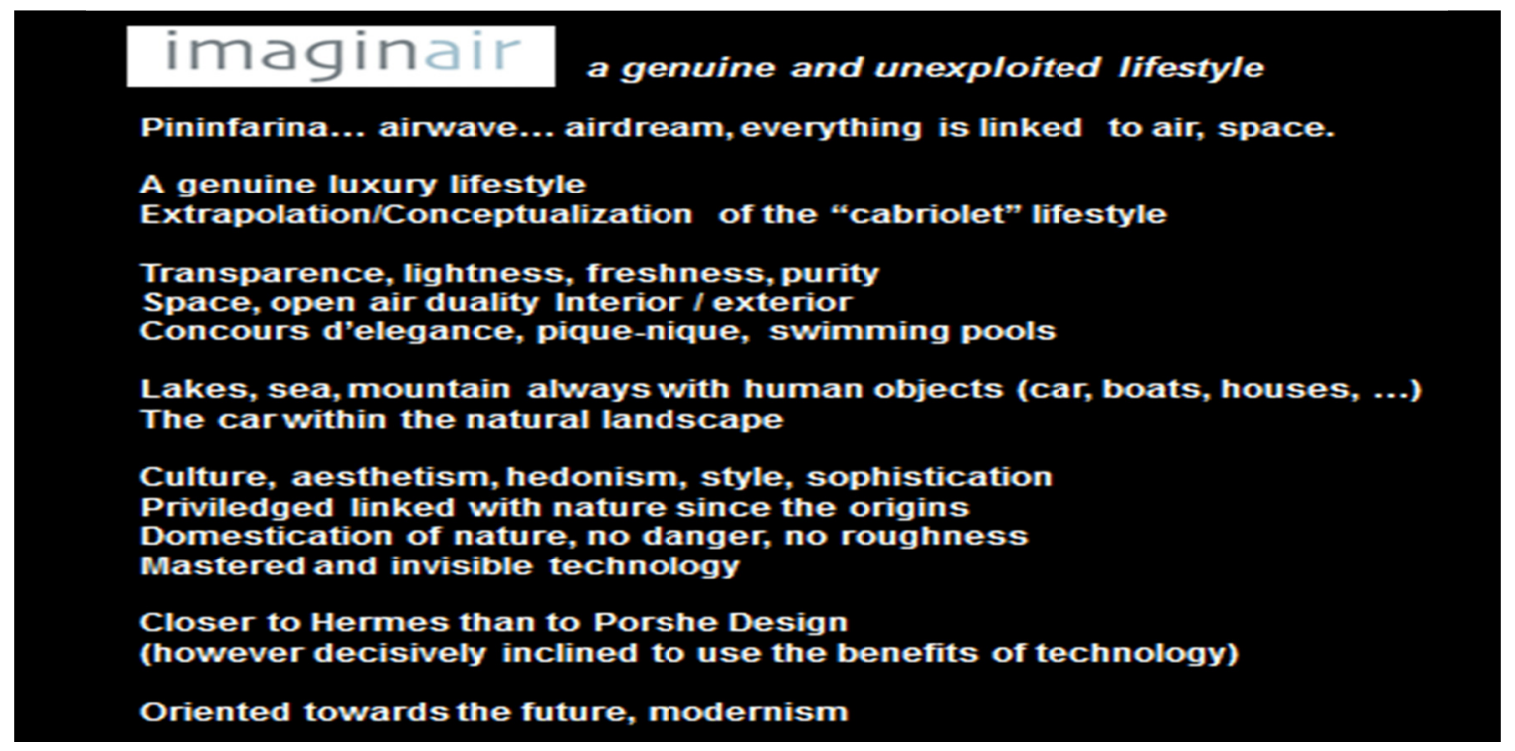

Figure 9. Pininfarina Brand Universe: Imaginair

These Pininfarina implications can possibly be inferred to similar cases of transformation from B2B designer to B2C brand.

\section{Limitations}

This research paper has all the limits of case studies (Flyvbjerg, 2006; Hodkinson \& Hodkinson, 2001):

The complexity of the reality observed is necessarily oversimplified by the analytical schemes applied. The notion of brand identity, for example, cannot grasp all of the wealth of defining characteristics of a brand.

The lessons derived from the study are not necessarily generalizable to other cases, the context being unique and irreproducible.

The enormous amount of data available has been a source of analytical difficulties. The 80 years of well-documented Pininfarina's car designs and communication required making choices on what looked to us as the most meaningful. We were also limited by the 3 month time framework of the project.

Moreover, we have chosen the notion of brand identity rather than brand personality in order to create a managing instrument to offer guidelines all persons who would promote the brand through creation and communication. The 2 approaches are currently used by academics and practitioners. Along with Azoulay \& Kapferer, (2003), who write: "Brand personality is a useful concept, but brand identity has more facets than 
the personality facet alone." we believe that the notion of identity is richer and more rigorous especially in its semiotic approach.

\section{Originality/Values}

There are no documented examples of the passage from B2B designer to B2C Company. This has been a unique opportunity to be called by one of the greatest car designer, in order to help in this transition. We had this rare chance of grounding our study in an actual ground reality, revealing all the complexity of design projects and helping us in understanding the complex inter-relationships of design teams.

Furthermore, this study has proven that in a case of inter-departments tensions, participation to common projects may help in their resolution. However, two conditions seem indispensable:

The top Management support to the project is fundamental.

The department teams need to be convinced of the usefulness of the project results.

This has also been a unique opportunity to apply to its fullest extent a semiotic approach to brand definition and management. The results have been presented up to the board level and accepted (and used) by the staff and executives in communication and design. The process has also confirmed the validity of the ESTET diagram as a diagnostic tool of coherence of brand manifestations with respect to brand identities.

\section{Conclusion}

One axis of further research would be return to the same company a few years later and observe whether the consensus built during the common project lasted over time.

Comparisons with similar common projects in different fields as strategy, organization, and diversification could also be fruitful in our understanding of the processes of attitudes changes in corporate environment.

As for Pininfarina Company, the case study had a major direct and lasting impact on the management. It served as a guideline to all the company development and communication activities. The most spectacular has been the concept car "Sintesi" presented at the Geneva car show in 2008. The project had been conceived by the Chief Designer and AP to present and respect all the factors of the Pininfarina's brand identity as formalized by the study.

The website (accessed on October $24^{\text {th }} 2014$ ) language shows also that the results of the work done on the brand identity are present in the brand communication. We can read for instance that: "Pininfarina DNA today is the same as in the thirties: the centrality of the design, the aesthetic sensibility capable of creating timeless beauty, the constant striving for innovation, the strength of a tradition that brings together industry, technology, and stylistic research, the ability to interpret the client's needs without altering the brand identity."

Since Andrea Pininfarina's death on August 7th 2008 in a Vespa accident, the brand development project has been held, waiting for new investors to restructure the group and mobilize the necessary financial resources to launch the implementation of the brand in terms of mono-branded products and services.

\section{Acknowledgments}

We are grateful to the late Andrea Pininfarina who was the enthusiastic initiator of the project and his brother Paolo who is now the President of the company.

The Design Director Lowie Veermersch was an essential contributor to the final results of the project as well as a key motivator of the design teams. Special thanks to Jean-Christophe Villain, the Design specialist of the consulting team without him the project could not have prospered.

\section{References}

Aaker, D. A. (1996). Building Strong Brands. New York: The Free Press.

Azoulay, A., \& Kapferer, J. F. (2003). Do Brand Personality Scales Really Measure Brand Personality? Brand Management, 11(2), 143-155. http://dx.doi.org/10.1057/palgrave.bm.2540162

Burmann, C., Jost-Benz, M., \& Riley, N. (3009). Towards an Identity-based Brand Equity Model. Journal of Business Research, 62, 390-397. http://dx.doi.org/10.1016/j.jbusres.2008.06.009

Chevalier, M., \& Mazzalovo, G. (2004). Pro Logo: Brands as a Factor of Progress. UK: Palgrave MacMillan.

Chevalier, M., \& Mazzalovo, G. (2012). Luxury Brand Management. Singapore, Wiley \& Sons (second edition). http://dx.doi.org/10.1002/9781119199168

\footnotetext{
${ }^{7}$ Understood here as "brand identity invariants"
} 
Chiapello, E. (1998). Artistes versus Managers. Paris : Editions Métaillé.

Coquet, J. C. (1982). Sémiotique: L'Ecole de Paris. Paris : Hachette Université.

De Chernatony, L. (2006). From Brand Vision to Brand Evaluation. The Strategic Process of Growing and Strengthening Brands. 2ed. Oxford: Butterworth-Heinemann.

Dion, D., \& De Boissieu, E. (2013). Construction et mise en scène d'un lignage : le cas des chefs dans la haute cuisine. Décision Marketing, 70. http://dx.doi.org/10.7193/dm.070.25.42

Eisenhardt, K. M. (1989). Building Theories from Case Study Research. Academy of Management Review, 14(4).

Floch, J. M. (1990). Sémiotique, Marketing et Communication. Sous les signes, les stratégies. Paris: Presses Universitaires de France.

Floch, J. M. (1995). Identités visuelles. Paris : Presses Universitaires de France.

Flyvbjerg, B. (2006). Five Misunderstandings about Case-Study Research. Qualitative Enquiry, 12(2). http://dx.doi.org/10.1177/1077800405284363

Groupe, U. (1992). Traite du Signe Visuel : Pour une Réthorique de l'Image. Paris: Seuil.

Heilbrunn, B. (2000). La Marque : Métaphore Vive Ou Métaphore Vide ? Conférence Le tendenze del Marketing in Euopa. Università Ca'Foscari. Venezia..

Hjelmslev, L. (1971). Essais linguistiques. Paris : Editions de Minuit.

Hodkinson, P., \& Hodkinson, H. (2001). The Strengths and Limitations of Case Study Research. Paper presented to the Learning and Skills Development Agency conference" Making an Impact on Policy and Practice". [online] Cambridge, 5-7 December 2001. http://education.exeter.ac.uk/tlc/docs/publications/LE_PH_PUB_05.12.01.rtf [accessed 22 October 2014].

Janson, H. W. (1995) History of Art. 5th edition. Revised and expanded by Anthony F. Janson. London: Thames \& Hudson

Johansson, U., \& Holm, L. S. (2006). Brand Management and Design Management. In: Brand culture by Schroeder J. and Salzer-Moerling M. New York: Routledge.

Kapferer, J. N. (1992). Strategic Brand Management: New Approaches to Creating and Evaluating Brand Equity. London: Kogan Page.

Koch, C. H. (2014). Corporate Brand Positioning: Case Studies across Firm Levels and Over Time. Lund University, School of Economics and Management.

Langley, A. (2011). Studying Process In and Around Organizations. In D.Buchanan, \& A.Bryman (Eds.). The Sage handbook of organizational research methods. London, UK: Sage publications.

Lendrevie, J., Levy, J., \& Lindon D. (2009). Mercator : Théories et nouvelles pratiques du Marketing. Paris: Dunod.

Mazzalovo, G. (2012). Brand Aesthetics. London: Palgrave Macmillan. http://dx.doi.org/10.1057/9781137025609

Mazzalovo, G., \& Darpy, D. (2014). Gestion Expressive des Marques dans un Contexte de Baroquisation. Décisions Marketing, DM 74, 83 - 96.

Michlewski, K. (2008). Uncovering Design Attitude: Inside the Culture of Designers. Organization Studies, 29 (3), 373-392. http://dx.doi.org/10.1177/0170840607088019

Monga, A. B., \& John, D. R. (2010). What Makes Brands Elastic? The Influence of Brand Concept and Styles of Thinking on Brand Extension Evaluation. Journal of Marketing, 74(3), 80-92. http://dx.doi.org/10.1509/jmkg.74.3.80

Moore, C. M., Fernie, J., \& Burt, S. (2000). Brands without boundaries. The internationalization of the designer retailer's brand. European Journal of Marketing, 34(8), 919-936. http://dx.doi.org/10.1108/03090560010331414

O’Shaughnessy, J. (1987). Why People Buy. Oxford: University Press.

Pininfarina, B. (1968). Pininfarina. Nato con l'Automobile. Memorie raccolte da Ernesto Caballo. Milano: Palazzi Editore.

Ricœur, P. (1990). Soi-même comme un autre. Paris : Editions du Seuil.

Saussure de, F. [1916 (2005)]. Cours de linguistique générale. Paris : Payot. 
Semprini, A. (1997). Le Marketing de la marque. Paris : Editions Liaisons..

Semprini, A. (2005). La marque, une puissance fragile. Paris: Vuibert.

Stern, I., \& Henderson, D. A. (2004). Within Business Diversification in Technology Intensive Industries. Strategic Management Journal, 25(5), 487-505. http://dx.doi.org/10.1002/smj.400

Upshaw, L. B. (1995). Building Brand Identity: a Strategy for Success in a Hostile Market Place. New York: John Wiley \& Sons.

Van De Ven, A. H. (2007). Engaged Scholarship. A Guide for Organizational and Social Research. Oxford, Oxford University Press.

This work is licensed under a Creative Commons Attribution 3.0 License. 